\title{
Household factors and the risk of severe COVID-like illness early in the US pandemic
}

Denis Nash ${ }^{1,5}$, Saba Qasmieh ${ }^{1}$, McKaylee Robertson ${ }^{1}$, Madhura Rane $^{1}$, Rebecca Zimba ${ }^{1}$, Sarah

Kulkarni ${ }^{1}$, Amanda Berry ${ }^{1}$, William You ${ }^{1}$, Chloe Mirzayi ${ }^{1}$, Drew Westmoreland ${ }^{1}$, Angela

Parcesepe ${ }^{3,4}$, Levi Waldron ${ }^{1,5}$, Shivani Kochhar ${ }^{1}$, Andrew R Maroko ${ }^{1,2}$, and Christian Grov ${ }^{1,6}$ for the CHASING COVID Cohort Study Team

1. Institute for Implementation Science in Population Health (ISPH), City University of New York (CUNY); New York City, New York USA

2. Department of Environmental, Occupational, and Geospatial Health Sciences, Graduate School of Public Health and Health Policy, City University of New York (CUNY); New York City, New York USA

3. Department of Maternal and Child Health, Gillings School of Public Health, University of North Carolina, Chapel Hill, NC, USA

4. Carolina Population Center, University of North Carolina at Chapel Hill, Chapel Hill, NC, USA

5. Department of Epidemiology and Biostatistics, Graduate School of Public Health and Health Policy, City University of New York (CUNY); New York City, New York USA

6. Department of Community Health and Social Sciences, Graduate School of Public Health and Health Policy, City University of New York (CUNY); New York City, New York USA

\section{Corresponding author:}

Denis Nash, Ph.D., MPH

55 W. 125th St.

New York, NY USA 10027.

Phone: +1-(917) 740-8714

Email: denis.nash@sph.cuny.edu

\begin{abstract}
Objective: To investigate the role of children in the home and household crowding as risk factors for severe COVID-19 disease.

Methods: We used interview data from 6,831 U.S. adults screened for the Communities, Households and SARS/CoV-2 Epidemiology (CHASING) COVID Cohort Study in April 2020.

Results: In logistic regression models, the adjusted odds ratio [aOR] of hospitalization due to COVID-19 for having (versus not having) children in the home was 10.5 (95\% Cl:5.7-19.1) among study participants living in multi-unit dwellings and $2.2(95 \%$ $\mathrm{Cl}$ :1.2-6.5) among those living in single unit dwellings. Among participants living in multi-unit dwellings, the aOR for COVID-19 hospitalization among participants with more than 4 persons in their household (versus 1 person) was 2.5 (95\% Cl:1.0- 6.1), and 0.8 (95\% Cl:0.15-4.1) among those living in single unit dwellings.

Conclusion: Early in the US SARS-CoV-2 pandemic, certain household exposures likely increased the risk of both SARS-CoV-2 acquisition and the risk of severe COVID-19 disease.
\end{abstract}


medRxiv preprint doi: https://doi.org/10.1101/2020.12.03.20243683; this version posted December 4, 2020. The copyright holder for this preprint (which was not certified by peer review) is the author/funder, who has granted medRxiv a license to display the preprint in perpetuity.

It is made available under a CC-BY-NC-ND 4.0 International license .

\section{Introduction:}

49 Crowded indoor settings and sustained close contact are associated with an increased

50 likelihood of SARS-CoV-2 spread. ${ }^{12}$ Stay-at-home orders and other non-pharmaceutical

51 measures, such as bans on mass gatherings and physical distancing, were effective in

52 curtailing community transmission. ${ }^{3,4}$ However, these measures may have resulted in

53 shifting the transmission of SARS-CoV-2 to within household settings where high attack

54 rates can occur, with high rates of hospitalization and death. ${ }^{4-7}$ Crowded households

55 can be environments conducive to transmission due to difficulties in maintaining

56 physical distance and effective isolation, 8,9 and when infected household members have

57 pre-symptomatic or asymptomatic infection.

59 There is growing evidence suggesting that asymptomatic infections contribute

60 substantially to transmission of SARS-CoV-2 ${ }^{10-12}$. Younger age may be an important

61 factor driving asymptomatic spread. Studies have shown differences in the presentation

62 of COVID-19 between adults and children, with children less likely than adults to be

63 symptomatic and less likely to present with severe COVID-19 disease. ${ }^{13-16}$

64 Counterintuitively, other studies have suggested that children may have viral load levels

65 that are comparable to those of adults, and that they could play a role in driving

66 SARS-CoV-2 transmission. ${ }^{17,18}$ One recent study in India found that children and young

67 adults accounted for $30 \%$ of cases. ${ }^{19}$ Moreover, the lack of mask use early in the US

68 pandemic indoors among members of the same household who may have been

69 asymptomatic or pre-symptomatic during the first several days of quarantine under 
medRxiv preprint doi: https://doi.org/10.1101/2020.12.03.20243683; this version posted December 4, 2020. The copyright holder for this preprint (which was not certified by peer review) is the author/funder, who has granted medRxiv a license to display the preprint in perpetuity. It is made available under a CC-BY-NC-ND 4.0 International license .

70 stay-at-home orders could have resulted in a higher inoculum and increased disease

71 severity. $20,21,22$

72

73 Household studies are important for understanding the role of factors such as

74 household crowding and household age composition on household SARS-CoV-2

75 transmission. A recent systematic review of 40 SARS-CoV-2 household transmission

76 studies suggests that, while the secondary attack rate within households is high $(18.8 \%$,

$7795 \% \mathrm{Cl}$ 15.4\%-22.2\%), transmission rates are highest: a) when the primary household

78 cases are symptomatic $(19.9 \%, 95 \% \mathrm{Cl}: 14.0 \%-25.7 \%)$ vs asymptomatic; b) among

79 adult contacts $(31 \%, 95 \% \mathrm{Cl}: 19.4 \%-42.7 \%)$ vs children; and c) in households with

80 only 1 other contact $(45.2 \%, 95 \% \mathrm{Cl} 34.1 \%-51.8)$ vs those with 3 or more contacts. ${ }^{2}$

81 Early studies in New York state showed high attack rates, hospitalizations, and deaths

82 within the households of index cases. ${ }^{6}$ And a recent household transmission study

83 conducted in Tennessee and Wisconsin by the CDC found a very high and rapidly

84 occurring secondary infection rate of $53 \%$ among household members of an index case,

85 with $>70 \%$ of secondary cases occurring within 5 days of symptom onset of the index

86 case. $^{5}$ The effect of household transmission versus other community transmission on

87 SARS-CoV-2 severity has not been systematically investigated.

89 Few household studies have examined the role of children on household transmission

90 of SARS-CoV-2, and those that have relied on small sample sizes. ${ }^{5,23,24}$ Understanding

91 the risk of COVID-19 in crowded households and households with children (regardless

92 of whether they are the primary case in the household) will be important in elucidating 
medRxiv preprint doi: https://doi.org/10.1101/2020.12.03.20243683; this version posted December 4, 2020. The copyright holder for this preprint (which was not certified by peer review) is the author/funder, who has granted medRxiv a license to display the preprint in perpetuity.

It is made available under a CC-BY-NC-ND 4.0 International license .

93 the impact of stay-at-home orders and prolonged indoor contact on the risk severe

94 infections. The objective of this study was to examine the effects of household

95 characteristics, primarily the presence of children in the household and household

96 crowding, on the risk of COVID hospitalization during the early phase of the

97 SARS-CoV-2 pandemic in the US.

98

99 Methods:

100 Study population:

101 Study participants were individuals screened for enrollment into the Communities,

102 Households, and SARS/CoV-2 Epidemiology (CHASING) COVID Cohort study who

103 completed an initial baseline assessment. The CHASING COVID Cohort study is a

104 national prospective cohort study of adults from the US and US territories that was

105 launched on March 28, 2020 to understand the spread and impact of the SARS-CoV-2

106 pandemic within households and communities. The survey methodology is described in

107 detail in a previous publication. ${ }^{25}$ Briefly, study participants were recruited online through

108 social media platforms or through referrals using advertisements that were in both

109 English and Spanish. The platform Qualtrics (Qualtrics, Provo, UT), an online survey

110 platform widely used in social and behavioral research, was used for data collection.

112 The initial baseline assessment captured information on household characteristics,

113 underlying risk factors, SARS-CoV-2 symptoms, and health-seeking behaviors such as

114 testing and hospitalizations. A second version of the initial baseline questionnaire was

115 launched on April 9, 2020 to capture healthcare and essential worker status. A total of 
medRxiv preprint doi: https://doi.org/10.1101/2020.12.03.20243683; this version posted December 4, 2020. The copyright holder for this preprint (which was not certified by peer review) is the author/funder, who has granted medRxiv a license to display the preprint in perpetuity. It is made available under a CC-BY-NC-ND 4.0 International license .

116 6,831 participants had completed an initial cohort screening interview by April 20, 2020.

117 The study protocol was approved by the Institutional Review Board at the City 118 University of New York (CUNY).

\section{Variable definitions:}

121 Primary Outcome:

122 The main outcome was self-report of hospitalization for COVID symptoms reported in

123 the two weeks prior to the interview. Symptoms assessed included any of the following:

124 fever, chills, rigors, runny nose, myalgia, headache, sore throat, stomach ache,

125 diarrhea, nasal congestion, nausea, vomiting, cough or coughing up blood or phlegm,

126 shortness of breath. Those reporting any of these symptoms who reported also being

127 hospitalized as a result of their reported symptoms were classified as having the

128 outcome; all other participants were classified as not having the outcome.

130 Primary and secondary exposures:

131 The primary exposure was the presence of any children under 18 years of age living in

132 participants' household. Secondary exposures were the number of persons living in a

133 household $(1,2-3$, more than 4$)$ and the type of property in which the participant lived.

134 Property type was classified as either a multi-unit property (e.g. apartment,

135 condominium, co-op, or building with two or more units), single-unit property (e.g.

136 detached home, or townhouse), or other.

138 Covariates: 
medRxiv preprint doi: https://doi.org/10.1101/2020.12.03.20243683; this version posted December 4, 2020. The copyright holder for this preprint (which was not certified by peer review) is the author/funder, who has granted medRxiv a license to display the preprint in perpetuity.

It is made available under a CC-BY-NC-ND 4.0 International license .

\section{9}

140 We identified socio-demographic, behavioral and employment factors as confounders of

141 hypothesized exposure-outcome relationships, including age, gender, race/ethnicity,

142 and annual combined income. Additionally, we included potential confounders such as

143 having had close contact with someone who had coronavirus-like symptoms and/or

144 having been involved in the diagnosis or care of someone with confirmed or suspected

145 coronavirus infection. Finally, we considered potential employment-related confounders,

146 including essential worker status, which was defined as having been involved in

147 following roles in the two weeks prior to survey date: healthcare, law enforcement, fire

148 department/first responder, delivery or pick-up services related to food or medications,

149 or in public/private transportation.

150

151 Community transmission:

152 As community transmission could confound the exposure-outcome relationship, we

153 used lagged population-based, county-level death rates as a proxy for community

154 transmission. We tabulated the number of COVID deaths per 100,000 population for

155 each county using data from the New York Times Github website (from 01/21/2020 to

156 07/05/2020). ${ }^{26}$ Our proxy for community SARS-CoV-2 transmission was a 5-day moving

157 average of COVID deaths per 100,000 population, lagged by 23 days. Specifically, to

158 use county death rates as a proxy for community transmission in the county, we

159 introduced a lag since COVID deaths follow several other milestones after infection

160 (infection $\rightarrow$ incubation $\rightarrow$ symptoms $\rightarrow$ progression/hospitalization $\rightarrow$ death). We

161 assumed that data on the number of deaths for a given day represented community 
medRxiv preprint doi: https://doi.org/10.1101/2020.12.03.20243683; this version posted December 4, 2020. The copyright holder for this preprint (which was not certified by peer review) is the author/funder, who has granted medRxiv a license to display the preprint in perpetuity. It is made available under a CC-BY-NC-ND 4.0 International license .

162 transmission that was occurring 23 days earlier, specifically 5 days from infection to 163 symptom onset (reflecting the average incubation period); 5 days from symptom onset 164 to pneumonia; and 13 days from pneumonia diagnosis to death. ${ }^{27}$ For those participants 165 reporting symptoms, we then matched reported timing of symptom onset with 166 community transmission levels 5 days earlier, corresponding to the average incubation 167 period for SARS-CoV-2. ${ }^{28-30}$

COVID-related illness

170 Frequencies of seven measures of COVID-related outcomes were generated to

171 examine the health-seeking behaviors of all participants who 1) reported COVID

172 symptoms ; 2) met the CSTE case definition for COVID-like illness which was defined

173 as reporting at least two of following symptoms: fever, chills, myalgia, headache, sore

174 throat, or at least one of the following: cough, shortness of breath ${ }^{31}$; 3) reported seeing 175 or calling a physician or healthcare professional for any of the COVID symptoms they

176 reported, 4) sought but were unable to get a diagnostic test, 5) received diagnostic test, 177 6) received a laboratory-confirmed diagnosis, or 7) were hospitalized for any of the 178 reported COVID symptoms. All measures were dichotomized as "yes" and "no" with 179 those who reported "do not know" or "not sure" were classified as a "no".

Comorbid conditions

182 Participants were asked whether they have been told by a health professional that they

183 had heart attack, angina or coronary heart disease, type 2 diabetes, high blood 
medRxiv preprint doi: https://doi.org/10.1101/2020.12.03.20243683; this version posted December 4, 2020. The copyright holder for this preprint (which was not certified by peer review) is the author/funder, who has granted medRxiv a license to display the preprint in perpetuity.

It is made available under a CC-BY-NC-ND 4.0 International license .

184 pressure, cancer, asthma, chronic obstructive pulmonary diseases, emphysema, or

185 chronic bronchitis, kidney disease, HIVIAIDS, immunosuppression, and depression.

187 Statistical Analysis:

188 Descriptive statistics were generated to examine the socio-demographic, health and

189 behavioral characteristics between households with and without children, and for

190 hospitalized and non-hospitalized participants. Frequencies were generated for all

191 categorical variables and Pearson's chi-squared test of independence was performed to

192 assess group differences.

194 A multivariable logistic regression model was used to estimate the association between

195 presence of children in households, number of people living in a household, and

196 property types on the risk of hospitalization with COVID symptoms. We ran three

197 models, all adjusted for age, gender, race/ethnicity, income, close contact, essential

198 worker status, and community transmission rate. Models examining the exposures of

199 the number of people living in household and property types models were also adjusted

200 for presence of children in the household. These variables chosen were based on

201 hypothesized causal associations and confounders, and direct acyclic graphs ${ }^{32}$ were

202 developed for each model.

203

204 Given the associations between household crowding with COVID transmission ${ }^{8,9}$, the

205 crude and multivariate associations between 1) presence of children in household or 2)

206 household size on hospitalizations due to COVID were stratified by property type. For 
medRxiv preprint doi: https://doi.org/10.1101/2020.12.03.20243683; this version posted December 4, 2020. The copyright holder for this preprint (which was not certified by peer review) is the author/funder, who has granted medRxiv a license to display the preprint in perpetuity.

It is made available under a CC-BY-NC-ND 4.0 International license .

207 each main effect model, we ran a model with an interaction term (i.e., presence of

208 children* property type and household size* property type) and adjusted for the same

209 covariates as the main effects models.

210

211 Finally, we described the socio-demographic and behavioral characteristics, as well as

212 comorbidities of participants who were hospitalized with COVID symptoms to those who

213 were not. These included socio-demographic characteristics, and health and behavioral

214 risk factors such as essential worker status, report of having comorbid conditions, and

215 whether participants were in close contact with symptomatic, suspected or confirmed

216 COVID cases. In addition, reported COVID symptoms were examined and ranked for

217 both groups.

218

219 Sensitivity analyses:

220 Three separate sensitivity analyses were performed to assess the potential impact of

221 missing data and misclassification. First, to assess the potential impact of missing

222 values of essential worker status in the initial baseline assessment, a complete case

223 analysis was performed on the participants who had completed the second version of

224 the baseline assessment and for whom essential worker status was known. Given the

225 negative impact of the COVID-19 pandemic on care seeking (including emergency room

226 care $)^{33}$, a second sensitivity analysis assessed the potential impact of excluding persons

227 with COVID symptoms who were not hospitalized in the non-hospitalized group (i.e.,

228 differential outcome misclassification). For this analysis we excluded persons who

229 reported symptoms from the denominator of non-hospitalized. The third sensitivity 
medRxiv preprint doi: https://doi.org/10.1101/2020.12.03.20243683; this version posted December 4, 2020. The copyright holder for this preprint (which was not certified by peer review) is the author/funder, who has granted medRxiv a license to display the preprint in perpetuity.

It is made available under a CC-BY-NC-ND 4.0 International license .

230 analysis examined the main effects of the exposures on those hospitalized that also had

231 a laboratory confirmed diagnosis for COVID. For this analysis we restricted the outcome

232 to include only those who reported being hospitalized and have received a

233 laboratory-confirmed diagnosis for COVID.

234

235 SAS version 9.4 (SAS Institute, Cary, NC) was used for all statistical analyses.

236

237 Results:

238 A total of 6,831 participants completed cohort screening, including 5,348 (78\%) who

239 completed the second version of the assessment with the question on essential

240 workers.

241

242 COVID-like illness outcomes:

243 Between March 28, 2020 and April 20, 2020, 58.5\% of the study population reported

244 symptoms in the two weeks prior to their study interview, with $25.7 \%(n=1754)$ of those

245 meeting the case definition for COVID-like illness ${ }^{31}$ (Figure 1). Twelve percent $(n=820)$

246 of the study population reported seeing a healthcare provider for these symptoms, $7.6 \%$

$247(n=518)$ sought SARS-CoV-2 testing but did not receive it, $5.2 \% \quad(n=357)$ received a

248 diagnostic test, $2.8 \%(n=188)$ received a laboratory confirmed diagnosis of coronavirus,

249 and $2.8 \%(n=191)$ reported being hospitalized for COVID-like symptoms $(69.6 \%$

$250(n=133)$ of whom reported laboratory confirmation of their diagnosis, and were

251 considered 'confirmed'). 
medRxiv preprint doi: https://doi.org/10.1101/2020.12.03.20243683; this version posted December 4, 2020. The copyright holder for this preprint (which was not certified by peer review) is the author/funder, who has granted medRxiv a license to display the preprint in perpetuity.

It is made available under a CC-BY-NC-ND 4.0 International license .

253 Compared to those without children $<18$ in the household (Table 1), participants with

254 children were more likely to be under 49 years old (81.2\% vs $60.5 \%)$, Hispanic (25.9\%

255 vs $13.9 \%)$, essential workers $(26.5 \%$ vs $18.8 \%)$, and more likely to report having had

256 close contact with someone with coronavirus-like symptoms or a confirmed case $(23.3 \%$

257 vs $16.0 \%$ ). Participants who completed the second version of the assessment were

258 similar to those who completed the first (data not shown).

259

260 Multivariate analysis:

261 Compared to participants without children in the home, those with children had 4.99

262 times the adjusted odds $(95 \% \mathrm{Cl}: 3.16-7.89)$ in being hospitalized for COVID symptoms

263 (Table 2). No associations were observed between households with more than four

264 persons and hospitalization for COVID symptoms (aOR:1.11; 95\%Cl: 0.49-2.47)

265 compared to one-person households. Participants who lived in a multi-unit property

266 compared to those living in a single-unit had $4.62(95 \% \mathrm{Cl}: 2.79-7.66)$ times higher

267 adjusted odds of being hospitalized.

268

269 When stratified by property type, compared to participants without children living in a

270 multi-unit property, participants with children living in multi-unit property had 10.47 times

271 the adjusted odds for being hospitalized for those symptoms (95\%Cl: 5.73-19.13).

272 Participants living in households with more than 4 people in multi-unit property had 2.46

273 times the adjusted odds $(95 \% \mathrm{Cl}: 0.99-6.08)$ of being hospitalized with COVID

274 symptoms than participants living alone in a multi-unit property. No other statistically 
medRxiv preprint doi: https://doi.org/10.1101/2020.12.03.20243683; this version posted December 4, 2020. The copyright holder for this preprint (which was not certified by peer review) is the author/funder, who has granted medRxiv a license to display the preprint in perpetuity.

It is made available under a CC-BY-NC-ND 4.0 International license .

275 significant associations were observed between household sizes on hospitalization

276 when stratified by property type.

278 Characteristics of hospitalized participants compared to those not hospitalized:

279 A total of 191 participants were hospitalized for their reported symptoms (Table 3).

280 Compared with all other participants $(n=6,638)$, those hospitalized were more likely to

281 be between the age of 18 and 49 years of age ( $84.4 \%$ vs $59.8 \%)$, male ( $82.2 \%$ vs

$28250.2 \%$ ), and Hispanic (70.7\% vs 12.2\%). Hospitalized participants were more likely to 283 report a comorbid condition $(85.4 \%$ vs $31.7 \%)$ and to have had contact with a

284 symptomatic case or suspected or confirmed case ( $76.4 \%$ vs $14.2 \%)$. They were also 285 more likely to be essential workers ( $80.1 \%$ vs $17.1 \%)$. Fever and sore throat were the 286 two most commonly reported symptoms which were reported by $71.7 \%$ and $70.2 \%$ of 287 participants, respectively. About $76.4 \%$ of hospitalized participants received a test, and $28869.6 \%$ of them received a laboratory-confirmed diagnosis.

\section{Discussion}

291 Our study suggests that certain household exposures at the beginning of the 292 SARS-CoV-2 pandemic in the US not only increased the risk of SARS-CoV-2 293 acquisition, but also increased the risk of severe COVID-19 disease, requiring 294 hospitalization. Household crowding and having children in the home were both strong 295 and independent risk factors for being hospitalized with SARS-CoV-2 early in the US

296 pandemic. Our findings have implications for public health recommendations in areas 297 and during times where the risk of household transmission of SARS-CoV-2 may be 
medRxiv preprint doi: https://doi.org/10.1101/2020.12.03.20243683; this version posted December 4, 2020. The copyright holder for this preprint (which was not certified by peer review) is the author/funder, who has granted medRxiv a license to display the preprint in perpetuity.

It is made available under a CC-BY-NC-ND 4.0 International license .

298 higher, such as immediately prior to and after issuing stay at home orders, when the

299 point prevalence of SARS-CoV-2 in the affected communities may be at its highest

300 level. Essential workers, families with children, and those living in crowded indoor

301 settings may be at particularly high risk for being hospitalized with SARS-CoV-2, and

302 tailored recommendations to reduce the risk of household transmission are needed

303 when community transmission is high.

304

305 Household transmission occurs rapidly after an index case introduces the infection and

306 with high household attack rates, can originate from both children and adults ${ }^{19}$, and are

307 associated with high rates of hospitalization and death. ${ }^{2,5,6}$

308

309 Early in the US pandemic, even when mask use was recommended and became the

310 norm outside the home, and even in areas where stay at home orders had been put in

311 place, mask use inside the home or other at-home risk mitigation measures were not

312 recommended except in situations where there were ill/infected persons (when 10-14

313 days of isolation using a separate bedroom and bathroom was recommended to reduce

314 household transmission). However, because of household crowding, a lack of space in

315 the households, or a need to go to work, provide childcare, or care for other

316 household/family measures, isolation of ill/infected persons and quarantine of those who

317 have had a high risk exposure (e.g., to a confirmed case) is not always feasible, and

318 other risk mitigation measures (e.g., mask wearing, opening windows) are therefore

319 needed. 
medRxiv preprint doi: https://doi.org/10.1101/2020.12.03.20243683; this version posted December 4, 2020. The copyright holder for this preprint (which was not certified by peer review) is the author/funder, who has granted medRxiv a license to display the preprint in perpetuity.

It is made available under a CC-BY-NC-ND 4.0 International license .

321

322

323

324

325 and susceptible persons, but these infections may be more likely to result in

326 asymptomatic or milder SARS-CoV-2 infection, because of a lower infectious dose. ${ }^{20}$ It

327 is therefore possible that a lack of mask use at home during quarantine and isolation

328 results in a higher infectious dose of SARS-CoV-2 than would occur with masks,

329 especially in smaller homes, with more household members, including children.

331 Stay at home orders usually go into effect when community transmission (and point 332 prevalence) is highest, and by definition, they increase the amount of time that 333 household members spend together indoors. Given this, the high attack rates of 334 SARS-CoV-2 within households, and the higher severity of SARS-CoV-2 infections that 335 can result from prolonged unmasked, indoor exposures when entire households are 336 quarantined, public health officials should consider recommending mask use and other 337 risk mitigation strategies (e.g., open windows, reduced close contact, frequent at-home 338 testing) in all households with more than one person for a period of time immediately 339 before and after stay at home orders go into effect.

340

341 Essential workers have several potential risks for SARS-CoV-2 infection, including

342 commuting and exposure while at work, but they also may be at higher risk for acquiring 343 or transmitting infection at home as well. In NYC and Chicago, a COVID-19 hotspot 
medRxiv preprint doi: https://doi.org/10.1101/2020.12.03.20243683; this version posted December 4, 2020. The copyright holder for this preprint (which was not certified by peer review) is the author/funder, who has granted medRxiv a license to display the preprint in perpetuity.

It is made available under a CC-BY-NC-ND 4.0 International license .

344 analysis found that hot spots had more household crowding, in NYC, and tended to be

345 middle income, working class neighborhoods that may have higher concentrations of

346 essential workers. $^{9}$

348 Our study, which included substantial numbers of essential workers who were

349 hospitalized, looked within households and described some of the risk factors for severe

350 COVID-19 early in the US pandemic. Essential workers with young children need

351 childcare, which could put their children at risk of infection. Children with SARS-CoV-2

352 infection have high enough viral load to transmit to others, and may be more likely to

353 have unrecognized infections. When children become ill, isolation may be even more

354 challenging than for adults, and adults providing care for them are at higher risk,

355 possibly of a more severe SARS-CoV-2 infection, especially when it is difficult to follow

356 infection control practices, such as mask wearing at home by all household members.

358 Our study has limitations worth noting. First, this was not a household transmission

359 study, and therefore we could not pinpoint household transmission as the likely source

360 of the infection that resulted in infection and hospitalization among our study

361 participants. We therefore cannot say whether and the extent to which household

362 transmission occurred, and if it did, when a child in the household was the source of

363 infection to our study participants. We also did not assess participants' mask use at

364 home. Finally, while we controlled for several possible confounders of the association of

365 household crowding and children in the home with SARS-CoV-2 risk, unmeasured

366 confounding could partially explain our observed associations. 
368 Our study also had some strengths. As a large epidemiologic cohort study, it was

369 possible to examine the association of several potentially important household-level risk

370 factors with a relatively rare outcome of SARS-CoV-2 hospitalization, while controlling

371 for potential confounding factors. We also had a geographically diverse sample that

372 included several essential workers. Finally, our findings were robust to the three

373 sensitivity analyses, which generated similar findings to the main analysis.

375 Conclusions

376 Early in the US SARS-CoV-2 pandemic, certain household exposures likely increased

377 the risk of both SARS-CoV-2 acquisition and the risk of severe COVID-19 disease

378 requiring hospitalization. These findings may have implications for mask wearing and

379 other mitigation strategies at home immediately prior to and immediately after 'stay at

380 home' orders go into effect.

\section{Funding}

383 Funding for this project is provided by the CUNY Institute for Implementation Science in

384 Population Health (cunyisph.org), the COVID-19 Grant Program of the CUNY Graduate

385 School of Public Health and Health Policy, and the National Institute Of Allergy and

386 Infectious Diseases of the National Institutes of Health under Award Number

387 UH3AI133675.

\section{Acknowledgements}


medRxiv preprint doi: https://doi.org/10.1101/2020.12.03.20243683; this version posted December 4, 2020. The copyright holder for this preprint (which was not certified by peer review) is the author/funder, who has granted medRxiv a license to display the preprint in perpetuity.

It is made available under a CC-BY-NC-ND 4.0 International license .

We would like to acknowledge the CHASING COVID Cohort Study participants for their

390

contributions to this research.

\section{References}

1. Nishiura $\mathrm{H}$, Oshitani $\mathrm{H}$, Kobayashi $\mathrm{T}$, et al. Closed environments facilitate secondary transmission of coronavirus disease 2019 (COVID-19). Epidemiology. Published online March 3, 2020.

2. Madewell ZJ, Yang Y, Longini IM, Halloran ME, Dean NE. Household transmission of SARS-CoV-2: a systematic review and meta-analysis of secondary attack rate. medRxiv. Published online July 31, 2020. doi:10.1101/2020.07.29.20164590

3. Xu J, Hussain S, Lu G, et al. Associations of Stay-at-Home Order and Face-Masking Recommendation with Trends in Daily New Cases and Deaths of Laboratory-Confirmed COVID-19 in the United States. Explor Res Hypothesis Med. Published online July 8, 2020:1-10.

4. Gudbjartsson DF, Helgason A, Jonsson $\mathrm{H}$, et al. Spread of SARS-CoV-2 in the Icelandic Population. N Engl J Med. 2020;382(24):2302-2315.

5. Grijalva CG. Transmission of SARS-COV-2 Infections in Households - Tennessee and Wisconsin, April-September 2020. MMWR Morb Mortal Wkly Rep. 2020;69. doi:10.15585/mmwr.mm6944e1

6. Rosenberg ES, Dufort EM, Blog DS, et al. COVID-19 Testing, Epidemic Features, Hospital Outcomes, and Household Prevalence, New York State-March 2020. Clin Infect Dis. Published online May 8, 2020. doi:10.1093/cid/ciaa549

7. Althoff KN, Coburn SB, Nash D. Contact tracing: Essential to the public health response and our understanding of the epidemiology of COVID-19. Clin Infect Dis. Published online June 11, 2020. doi:10.1093/cid/ciaa757

8. Cromer SJ, Lakhani CM, Wexler DJ, Burnett-Bowie S-AM, Udler M, Patel CJ. Geospatial Analysis of Individual and Community-Level Socioeconomic Factors Impacting SARS-CoV-2 Prevalence and Outcomes. medRxiv. Published online September 30, 2020. doi:10.1101/2020.09.30.20201830

9. Maroko AR, Nash D, Pavilonis BT. COVID-19 and Inequity: a Comparative Spatial Analysis of New York City and Chicago Hot Spots. J Urban Health. 2020;97(4):461-470.

10. Bai Y, Yao L, Wei T, et al. Presumed Asymptomatic Carrier Transmission of COVID-19. JAMA. 2020;323(14):1406-1407.

11. Zhang J, Wu S, Xu L. Asymptomatic carriers of COVID-19 as a concern for disease prevention and control: more testing, more follow-up. Biosci Trends. 2020;14(3):206-208.

12. Kimball A, Hatfield KM, Arons M, et al. Asymptomatic and Presymptomatic SARS-CoV-2 
medRxiv preprint doi: https://doi.org/10.1101/2020.12.03.20243683; this version posted December 4, 2020. The copyright holder for this preprint (which was not certified by peer review) is the author/funder, who has granted medRxiv a license to display the preprint in perpetuity. It is made available under a CC-BY-NC-ND 4.0 International license .

Infections in Residents of a Long-Term Care Skilled Nursing Facility - King County, Washington, March 2020. MMWR Morb Mortal Wkly Rep. 2020;69(13):377-381.

13. Lu X, Zhang L, Du H, et al. SARS-CoV-2 Infection in Children. N Engl J Med. 2020;382(17):1663-1665.

14. Yang R, Gui X, Xiong Y. Comparison of Clinical Characteristics of Patients with Asymptomatic vs Symptomatic Coronavirus Disease 2019 in Wuhan, China. JAMA Netw Open. 2020;3(5):e2010182.

15. Loconsole D, Caselli D, Centrone F, et al. SARS-CoV-2 Infection in Children in Southern Italy: A Descriptive Case Series. Int J Environ Res Public Health. 2020;17(17). doi:10.3390/ijerph17176080

16. Yousaf AR, Duca LM, Chu V, et al. A prospective cohort study in non-hospitalized household contacts with SARS-CoV-2 infection: symptom profiles and symptom change over time. Clin Infect Dis. Published online July 28, 2020. doi:10.1093/cid/ciaa1072

17. Jones TC, Mühlemann B, Veith T, et al. An analysis of SARS-CoV-2 viral load by patient age. doi:10.1101/2020.06.08.20125484

18. Heald-Sargent T, Muller WJ, Zheng X, Rippe J, Patel AB, Kociolek LK. Age-Related Differences in Nasopharyngeal Severe Acute Respiratory Syndrome Coronavirus 2 (SARS-CoV-2) Levels in Patients With Mild to Moderate Coronavirus Disease 2019 (COVID-19). JAMA Pediatr. Published online July 30, 2020. doi:10.1001/jamapediatrics.2020.3651

19. Laxminarayan R, Wahl B, Dudala SR, et al. Epidemiology and transmission dynamics of COVID-19 in two Indian states. Science. 2020;370(6517):691-697.

20. Gandhi M, Rutherford GW. Facial masking for Covid-19-potential for "variolation" as we await a vaccine. N Engl J Med. 2020;383(18):e101.

21. Guallar MP, Meiriño R, Donat-Vargas C, Corral O, Jouvé N, Soriano V. Inoculum at the time of SARS-CoV-2 exposure and risk of disease severity. Int J Infect Dis. 2020;97:290-292.

22. Gandhi M, Beyrer C, Goosby E. Masks Do More Than Protect Others During COVID-19: Reducing the Inoculum of SARS-CoV-2 to Protect the Wearer. J Gen Intern Med. 2020;35(10):3063-3066.

23. Teherani MF, Kao CM, Camacho-Gonzalez A, et al. Burden of illness in households with SARS-CoV-2 infected children. J Pediatric Infect Dis Soc. Published online August 11, 2020. doi:10.1093/jpids/piaa097

24. Maltezou HC, Vorou R, Papadima K, et al. Transmission dynamics of SARS-CoV-2 within families with children in Greece: A study of 23 clusters. J Med Virol. Published online August 7, 2020. doi:10.1002/jmv.26394

25. Robertson M, Kulkarni S, Berry A, et al. A national prospective cohort study of SARS/COV2 pandemic outcomes in the U.S.: The CHASING COVID Cohort. doi:10.1101/2020.04.28.20080630

26. nytimes. nytimes/covid-19-data. Accessed October 10, 2020. 
medRxiv preprint doi: https://doi.org/10.1101/2020.12.03.20243683; this version posted December 4, 2020. The copyright holder for this preprint (which was not certified by peer review) is the author/funder, who has granted medRxiv a license to display the preprint in perpetuity.

It is made available under a CC-BY-NC-ND 4.0 International license .

https://github.com/nytimes/covid-19-data

27. Wilson N, Kvalsvig A, Barnard LT, Baker MG. Case-Fatality Risk Estimates for COVID-19 Calculated by Using a Lag Time for Fatality. Emerg Infect Dis. 2020;26(6):1339-1441.

28. CDC. Coronavirus Disease 2019 (COVID-19). Published September 10, 2020. Accessed October 15, 2020. https://www.cdc.gov/coronavirus/2019-ncov/hcp/clinical-guidance-management-patients.ht $\mathrm{ml}$

29. Li Q, Guan X, Wu P, et al. Early Transmission Dynamics in Wuhan, China, of Novel Coronavirus-Infected Pneumonia. N Engl J Med. 2020;382(13):1199-1207.

30. Lauer SA, Grantz KH, Bi Q, et al. The Incubation Period of Coronavirus Disease 2019 (COVID-19) From Publicly Reported Confirmed Cases: Estimation and Application. Annals of Internal Medicine. 2020;172(9):577-582. doi:10.7326/m20-0504

31. Coronavirus Disease 2019 (COVID-19) | 2020 Interim Case Definition, Approved April 5, 2020. Accessed October 10, 2020. https://wwwn.cdc.gov/nndss/conditions/coronavirus-disease-2019-covid-19/case-definition/ 2020/

32. Pearl J. Causal diagrams for empirical research. Biometrika. 1995;82(4):669-688.

33. Czeisler MÉ, Marynak K, Clarke KEN, et al. Delay or Avoidance of Medical Care Because of COVID-19-Related Concerns - United States, June 2020. MMWR Morbidity and Mortality Weekly Report. 2020;69(36):1250-1257. doi:10.15585/mmwr.mm6936a4

34. How NOT. How to Select, Wear, and Clean Your Mask. https://www.cdc.gov/coronavirus/2019-ncov/prevent-getting-sick/about-face-coverings.html

8

87


medRxiv preprint doi: https://doi.org/10.1101/2020.12.03.20243683; this version posted December 4, 2020. The copyright holder for this preprint (which was not certified by peer review) is the author/funder, who has granted medRxiv a license to display the preprint in perpetuity.

\author{
It is made available under a CC-BY-NC-ND 4.0 International license.
}


medRxiv preprint doi: https://doi.org/10.1101/2020.12.03.20243683; this version posted December 4, 2020. The copyright holder for this preprint (which was not certified by peer review) is the author/funder, who has granted medRxiv a license to display the preprint in perpetuity.

It is made available under a CC-BY-NC-ND 4.0 International license .

505 Figure 1: SARS-CoV-2 symptoms among persons screened for enrollment in the 506 CHASING COVID Cohort Study, April 2020

$100.0 \%$

$80.0 \%$

507

$60.0 \%-58.5 \%$

$0.0 \%$
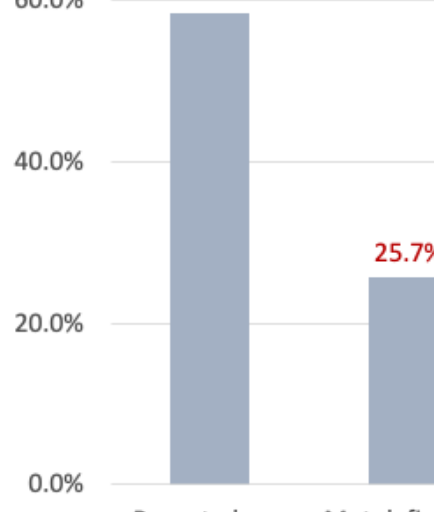

Reported any COVID symptoms for COVID-like

provider

$12.0 \%$

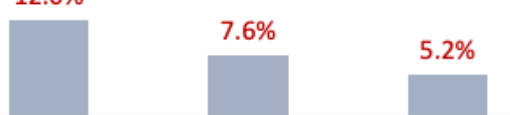

$2.8 \%$

$2.8 \%$

$$
\text { illness }
$$

Received lab- Hospitalized
confirmed
diagnosis

508

509

510

511

512

513

514

515

516

517

518

519

520

521

522

523

524

525

526 
527 Table 1: Select socio-demographic, health and behavior characteristics among persons screened for enrollment in the CHASING COVID Cohort ( $\mathrm{N}=6831)$, April 5292020

\begin{tabular}{|c|c|c|c|c|}
\hline \multicolumn{5}{|c|}{ Presence of Children in Household } \\
\hline & Total & Yes & No & p-value \\
\hline & $\mathbf{N}(\%)$ & n (\%) & n (\%) & \\
\hline Total & 6831 & $1547(22.7 \%)$ & $5284(77.4 \%)$ & \\
\hline \multicolumn{5}{|l|}{ Socio-demographic } \\
\hline \multicolumn{5}{|l|}{ Age group (years) } \\
\hline $18-49$ & $4133(60.5 \%)$ & $1256(81.2 \%)$ & $2877(54.5 \%)$ & \multirow{3}{*}{$<0.0001$} \\
\hline $50-59$ & $1083(15.9 \%)$ & $192(12.4 \%)$ & $891(16.9 \%)$ & \\
\hline $60+$ & $1615(23.6 \%)$ & $99(6.4 \%)$ & $1516(28.7 \%)$ & \\
\hline \multicolumn{5}{|l|}{ Gender } \\
\hline Male & $3487(51.1 \%)$ & $575(37.2 \%)$ & $2912(55.1 \%)$ & \multirow{3}{*}{$<0.0001$} \\
\hline Female & $3134(45.9 \%)$ & $939(60.7 \%)$ & $2195(41.5 \%)$ & \\
\hline Gender non-binary & $210(3.1 \%)$ & $33(2.1 \%)$ & $177(3.4 \%)$ & \\
\hline \multicolumn{5}{|l|}{ Race/ethnicity } \\
\hline Hispanic & $946(13.9 \%)$ & $401(25.9 \%)$ & $545(10.3 \%)$ & \multirow{5}{*}{$<0.0001$} \\
\hline White & $4561(66.8 \%)$ & $828(53.5 \%)$ & $3733(70.7 \%)$ & \\
\hline Black non-Hispanic & $721(10.6 \%)$ & $176(11.4 \%)$ & $545(10.3 \%)$ & \\
\hline Asian/Pacific Islander & $326(4.8 \%)$ & $81(5.2 \%)$ & $245(4.6 \%)$ & \\
\hline Other & $277(4.1 \%)$ & $61(3.9 \%)$ & $216(4.1 \%)$ & \\
\hline \multicolumn{5}{|l|}{ Income level } \\
\hline$<50,000$ & $3253(47.6 \%)$ & $665(43.0 \%)$ & $2588(49.0 \%)$ & \multirow{4}{*}{$<0.0001$} \\
\hline $50,000-99,000$ & $1626(23.8 \%)$ & $298(19.3 \%)$ & $1328(25.1 \%)$ & \\
\hline 100,000 & $1530(22.4 \%)$ & $446(28.8 \%)$ & $1084(20.5 \%)$ & \\
\hline Not reported & $422(6.2 \%)$ & $138(8.9 \%)$ & $284(5.4 \%)$ & \\
\hline \multicolumn{5}{|l|}{ Health and behaviors } \\
\hline \multicolumn{5}{|l|}{ Essential worker } \\
\hline Yes & $1286(18.8 \%)$ & $410(26.5 \%)$ & $876(16.6 \%)$ & \multirow{3}{*}{$<0.0001$} \\
\hline No & $4062(59.5 \%)$ & $865(55.9 \%)$ & $3197(60.5 \%)$ & \\
\hline Not asked & $1483(21.7 \%)$ & $272(17.6)$ & $1211(22.9 \%)$ & \\
\hline \multicolumn{5}{|l|}{$\begin{array}{l}\text { Reported having } \\
\text { comorbidities }\end{array}$} \\
\hline Yes & $2271(33.2 \%)$ & $488(31.5 \%)$ & $3501(66.3 \%)$ & \multirow{2}{*}{0.1065} \\
\hline No & $4560(66.8 \%)$ & $1059(68.5 \%)$ & $1783(33.7 \%)$ & \\
\hline \multicolumn{5}{|l|}{$\begin{array}{l}\text { Had close contact } \\
\text { with } \\
\text { suspected/confirmed } \\
\text { case }\end{array}$} \\
\hline Yes & $1090(16.0 \%)$ & $361(23.3 \%)$ & $729(13.8 \%)$ & \multirow{2}{*}{$<0.0001$} \\
\hline No & $5741(84.0 \%)$ & $1186(76.7 \%)$ & $4555(86.2 \%)$ & \\
\hline \multicolumn{5}{|l|}{ Household Factors } \\
\hline \multicolumn{5}{|l|}{ Property type } \\
\hline Multi-unit property & $2602(38.1 \%)$ & $451(29.2 \%)$ & $2151(40.7 \%)$ & \multirow{3}{*}{$<0.0001$} \\
\hline Single-unit property & $3856(56.5 \%)$ & $985(63.7 \%)$ & $2871(54.3 \%)$ & \\
\hline Other & $373(5.5 \%)$ & $111(7.2 \%)$ & $262(5.0 \%)$ & \\
\hline \multicolumn{5}{|l|}{$\begin{array}{l}\text { Number of persons } \\
\text { living in } \mathrm{HH}\end{array}$} \\
\hline 1 & $1990(29.1 \%)$ & 0 & $1190(37.7 \%)$ & \multirow{3}{*}{$<0.0001$} \\
\hline $2-3$ & $3157(46.2 \%)$ & $394(25.5 \%)$ & $277863(52.3 \%)$ & \\
\hline $4+$ & $1684(24.7 \%)$ & $1153(74.5 \%)$ & $531(10.1 \%)$ & \\
\hline
\end{tabular}


536 Table 2: Main effects of presence of children, number of persons in households and property type on hospitalization for COVID-like symptoms $(\mathrm{N}=6831)$, April

\begin{tabular}{|c|c|c|c|c|}
\hline \multirow{2}{*}{\multicolumn{2}{|c|}{ Main exposures }} & \multicolumn{3}{|c|}{ Hospitalized with COVID symptoms } \\
\hline & & n (\%) & cOR $(95 \% \mathrm{CI})$ & aOR $(95 \% \mathrm{CI})$ \\
\hline \multirow{29}{*}{541} & Children in household* & & & \\
\hline & Yes & $147(9.5 \%)$ & $12.51(8.89-17.61)$ & $4.99(3.16-7.89)$ \\
\hline & No & $44(0.8 \%)$ & ref & ref \\
\hline & Number of persons in household $* *$ & & & \\
\hline & 1 & $18(0.9 \%)$ & ref & ref \\
\hline & $2-3$ & $34(1.1 \%)$ & $1.19(0.67-2.12)$ & $0.90(0.45-1.79)$ \\
\hline & More than 4 & $139(8.3 \%)$ & $9.85(6.00-16.17)$ & $1.11(0.49-2.47)$ \\
\hline & Property Type *** & & & \\
\hline & Multi-Unit & $153(5.9 \%)$ & $8.86(5.87-13.38)$ & $4.62(2.79-7.66)$ \\
\hline & Single-Unit & $27(0.7 \%)$ & ref & ref \\
\hline & Other & $11(3.0 \%)$ & $4.31(2.12-8.76)$ & $4.55(2.00-10.36)$ \\
\hline & Interactions & & & \\
\hline & $\begin{array}{l}\text { Presence of children stratified by } \\
\text { property }\end{array}$ & & & \\
\hline & Children living multi-unit & $131(29.1 \%)$ & $39.60(24.83-63.14)$ & $10.47(5.73-19.13)$ \\
\hline & No children living in multi-unit & $22(1.0 \%)$ & ref & ref \\
\hline & Children living in single unit & $12(1.2 \%)$ & $2.35(1.10-5.04)$ & $2.82(1.23-6.47)$ \\
\hline & No children living in single unit & $15(0.5 \%)$ & ref & ref \\
\hline & Children living in 'other' type unit & $4(3.6 \%)$ & $1.36(0.39-4.75)$ & $1.05(0.27-4.14)$ \\
\hline & No children living in 'other' type unit & $7(2.7 \%)$ & ref & ref \\
\hline & $\begin{array}{l}\text { Household size stratified by } \\
\text { property type }\end{array}$ & & & \\
\hline & 1 living in multi-unit & $13(1.1 \%)$ & ref & ref \\
\hline & 2-3 living in multi-unit & $16(1.6 \%)$ & $1.41(0.68-2.95)$ & $1.13(0.48-2.64)$ \\
\hline & More than 4 living in multi-unit & $124(26.4 \%)$ & $31.05(17.32-55.68)$ & $2.46(0.99-6.08)$ \\
\hline & 1 living in single unit & $2(0.3 \%)$ & ref & ref \\
\hline & 2-3 living in single unit & $15(0.7 \%)$ & $2.73(0.62-11.98)$ & $1.62(0.36-7.38)$ \\
\hline & More than 4 living in single unit & $10(0.9 \%)$ & $3.37(0.74-15.41)$ & $0.78(0.15-4.06)$ \\
\hline & 1 living in other type unit & $3(2.5 \%)$ & ref & ref \\
\hline & 2-3 living in other type unit & $3(2.2 \%)$ & $0.87(0.17-4.41)$ & $0.70(0.10-5.707)$ \\
\hline & More than 4 living in other type unit & $5(4.2 \%)$ & $1.71(0.40-7.33)$ & $0.85(0.14-5.30)$ \\
\hline
\end{tabular}

542 * Presence of children effects are adjusted for age, gender, race/ethnicity, close contact, income, county

543 mortality rate and essential worker status

$544{ }^{* *}$ Household size effects are adjusted for presence of children, age, gender, race/ethnicity, close contact, 
medRxiv preprint doi: https://doi.org/10.1101/2020.12.03.20243683; this version posted December 4, 2020. The copyright holder for this preprint (which was not certified by peer review) is the author/funder, who has granted medRxiv a license to display the preprint in perpetuity.

It is made available under a CC-BY-NC-ND 4.0 International license .

545 income, county mortality rate and essential worker status

$54{ }^{* * *}$ Property type effects are adjusted for presence of children, age, gender, race/ethnicity, close contact,

547 income, county mortality rate and essential worker status

548

549

550

\section{1}

552

Table 3: Characteristics of participants by status of hospitalization with COVID-like symptoms, April 2020

\begin{tabular}{|c|c|c|c|}
\hline \multirow[b]{2}{*}{ Socio-demographic Factors } & \multicolumn{3}{|c|}{ Hospitalized with COVID-symptoms } \\
\hline & $\begin{array}{c}\text { Yes } \\
\text { n }(\%)\end{array}$ & $\begin{array}{c}\text { No } \\
\mathrm{n}(\%)\end{array}$ & p-value \\
\hline \multicolumn{4}{|l|}{ Age group (years) } \\
\hline $18-49$ & $162(84.8 \%)$ & $3969(59.8 \%)$ & \multirow{3}{*}{$<0.0001$} \\
\hline $50-59$ & $8(4.2 \%)$ & $1075(16.2 \%)$ & \\
\hline $60+$ & $21(11.0 \%)$ & $1594(24.0 \%)$ & \\
\hline \multicolumn{4}{|l|}{ Gender } \\
\hline Male & $157(82.2 \%)$ & $3329(50.2 \%)$ & \multirow{3}{*}{$<0.0001$} \\
\hline Female & $31(16.2 \%)$ & $3102(46.7 \%)$ & \\
\hline Non-binary & $3(1.6 \%)$ & $207(3.1 \%)$ & \\
\hline \multicolumn{4}{|l|}{ Race/ethnicity } \\
\hline Hispanic & $135(70.7 \%)$ & $811(12.2 \%)$ & \multirow{5}{*}{$<0.0001$} \\
\hline White & $29(15.2 \%)$ & $4531(68.3 \%)$ & \\
\hline Black non-Hispanic & $19(10.3 \%)$ & $702(10.6 \%)$ & \\
\hline Asian/Pacific Islander & $2(1.1 \%)$ & $324(4.9 \%)$ & \\
\hline Other & $6(3.1 \%)$ & $270(4.1 \%)$ & \\
\hline Income level & & & \multirow{5}{*}{$<0.0001$} \\
\hline$<50,000$ & $50(26.2 \%)$ & $3202(48.2 \%)$ & \\
\hline $50,000-99,000$ & $14(7.3 \%)$ & $1612(24.3 \%)$ & \\
\hline 100,000 & $123(64.4 \%)$ & $1407(21.2 \%)$ & \\
\hline Missing & $4(2.1 \%)$ & $417(6.3 \%)$ & \\
\hline \multicolumn{4}{|l|}{$\begin{array}{l}\text { Health and behavioral } \\
\text { Factors }\end{array}$} \\
\hline \multicolumn{4}{|l|}{$\begin{array}{l}\text { Reported having } \\
\text { comorbidities }\end{array}$} \\
\hline Yes & $165(85.4 \%)$ & $2105(31.7 \%)$ & \multirow{2}{*}{$<0.0001$} \\
\hline No & $26(13.6 \%)$ & $4533(68.3 \%)$ & \\
\hline \multicolumn{4}{|l|}{$\begin{array}{l}\text { Had contact with } \\
\text { symptomatic or } \\
\text { suspected/confirmed case }\end{array}$} \\
\hline Yes & $146(76.4 \%)$ & $944(14.2 \%)$ & \multirow{2}{*}{$<0.0001$} \\
\hline No & $45(23.6 \%)$ & $5694(85.8 \%)$ & \\
\hline \multicolumn{4}{|l|}{ Essential Worker } \\
\hline Yes & $153(80.1 \%)$ & $1133(17.1 \%)$ & \multirow{3}{*}{$<0.0001$} \\
\hline No & $29(15.2 \%)$ & $4032(60.7 \%)$ & \\
\hline Not asked & $9(4.7 \%)$ & $1473(22.2 \%)$ & \\
\hline
\end{tabular}


medRxiv preprint doi: https://doi.org/10.1101/2020.12.03.20243683; this version posted December 4, 2020. The copyright holder for this preprint (which was not certified by peer review) is the author/funder, who has granted medRxiv a license to display the preprint in perpetuity.

It is made available under a CC-BY-NC-ND 4.0 International license .

\begin{tabular}{|c|c|c|c|}
\hline $\begin{array}{l}\text { Reported symptoms } \\
\text { (ranked) }\end{array}$ & & & \\
\hline Fever & $137(71.7 \%)$ & $314(4.7 \%)$ & $<0.0001$ \\
\hline Sore throat & $134(70.2 \%)$ & $924(13.9 \%)$ & $<0.0001$ \\
\hline Headache & $32(16.8 \%)$ & $1867(28.1 \%)$ & 0.0005 \\
\hline Myalgia & $31(16.2 \%)$ & $758(11.4 \%)$ & 0.040 \\
\hline Cough with phlegm & $30(15.7 \%)$ & $831(12.5 \%)$ & 0.191 \\
\hline Shortness of breath & $28(14.7 \%)$ & $571(8.6 \%)$ & 0.004 \\
\hline New cough & $27(14.4 \%)$ & $769(11.6 \%)$ & 0.279 \\
\hline Runny nose & $26(13.6 \%)$ & $1641(24.7 \%)$ & 0.0004 \\
\hline Diarrhea & $22(11.5 \%)$ & $853(12.9 \%)$ & 0.587 \\
\hline Nasal congestion & $21(11.0 \%)$ & $1415(21.3 \%)$ & 0.0006 \\
\hline Chills & $18(9.4 \%)$ & $360(5.4 \%)$ & 0.017 \\
\hline Nausea & $15(7.9 \%)$ & $402(6.1 \%)$ & 0.306 \\
\hline Vomit & $9(4.7 \%)$ & $82(1.2 \%)$ & $<0.0001$ \\
\hline Cough with blood & $3(1.6 \%)$ & $19(0.3 \%)$ & 0.002 \\
\hline $\begin{array}{l}\text { Saw healthcare provider for } \\
\text { symptoms }\end{array}$ & & & \\
\hline Yes & $173(90.6 \%)$ & $646(9.7 \%)$ & \multirow{2}{*}{$<0.0001$} \\
\hline No & $18(9.4 \%)$ & $5992(90.3 \%)$ & \\
\hline Testing status & & & \\
\hline Sought test & $18(9.4 \%)$ & $500(7.5 \%)$ & \multirow{3}{*}{$<0.0001$} \\
\hline Received test & $146(76.4 \%)$ & $211(3.2 \%)$ & \\
\hline Did not need or try & $27(14.1 \%)$ & $5927(89.3)$ & \\
\hline $\begin{array}{l}\text { Received lab-confirmed } \\
\text { diagnosis }\end{array}$ & & & \\
\hline Yes & $133(69.6 \%)$ & $55(0.8 \%)$ & \multirow{2}{*}{$<0.0001$} \\
\hline No & $58(30.4 \%)$ & $6583(99.2 \%)$ & \\
\hline
\end{tabular}

